\title{
農業労働力の継承性からみた 中山間集落の農地保全に関する研究
}

Farmland Conservation in a Settlement of Hilly and Mountainous Farming Area from the Viewpoint of Continuity of Agricultural Labor Force

\section{藍澤 宏*.斎尾直子*. 石澤 学* \\ Hiroshi Aizawa, Naoko SaIo and Manabu Ishizawa}

\section{I 研究の背景と目的}

全国的な趃勢として，近年，農業の主労働力の 高齡化や後継者不足等の，担い手の質的・量的な 不足を起因として, 耕作放萧化・荒廃化といった, 農地の利用と保全に関する多くの課題が生じてい る。特に, 農業条件や生活条件が不利な中山間地 域では, このような傾向が顕著であり，個々の晨 地の利用形龍においても，現況の農業労働力に対 して「農地が余っている，管理しきれない」等の 農業経営上の課題が深刻化している。今後の中山 間地域という条件不利地域における農地を，有効 に利用し適切な保全管理を行うためには，農地の 保全主体である中核的農家とその農業労働力をい かに確保するかが重要な課題となる。加えて, 地 域全体の農地保全に関しては, 農地を所有する個 々の農家の同居家族のみならず, 別居家族や親戚, さらには地域営農を視野に入れ，地域社会をも考 㦄していくことが, 将来ますます必要になってく ると考えられる。

本研究では，このような背景を踏まえ，農村社 会の基本単位である集落を研究対象とし，集落の 土地利用を農家の所有農地に対する農業労働力

(䟴業の担い手としての運用能力)の継承性注1) からみることにより，中山間集落における農地保 全の方向性を求めることを目的とする。

\section{II 研究の方法}

本研究では, 農村社会の基本単位である「集落」
という範囲の中で，地域として農業を維持すると いうことに視点をおき，地域全体での合理的な農 地の保全担保を検討する。

まず，集落内農地の所有・利用構造を求めるた め, 農地筆の地理的分布と所有・利用者の集落と の関係，集落内での位瞢づけを把握する。さらに， 㖘地を保全し利用していく主体である個々の農家 について, 農業労働力の状況を把握し，その対象 である宸地との関係を明らかにする。そして，各 農家の労㗢力の継承状況と継承の可能性, また農 業継承の背其基盤となる個人の農業観を分析する ことにより，農地保全の方向性を明らかにする。

具体的には，第一に，集落内農家の土地所有 · 利用状況から, 農地の所有・利用の集皘単位とし てどのような籍囲が存在するかを明らかにするた め, 集落内の農業経営に開わる地縁集団の構成と その機能・役割, 並びに各農家の農地の所有領域, その集団的所有の分布形態の特徽を分析考察する。

第二に，将来にわたる農地保全の担い手として， 運用主体である個々の農家について労倠力の状況 を捉え，イエ及び農業経営の継承状況を背景とし た, 将来にわたる宸業労倒力確保の内容を明らか にする。既往研究注2)では，農業の継続性を農業 後継者の存在等, 主に直系家族について考察して いるが，本研究では継承の箅囲を，「親一子の直 系家族」「親の兄弟を含む傍系家族」，さらに「周 辺農家や地域組織等の第三者」にわたる範囲まで 捉える。

第三は，農業継承及び農地保全の質的要因とし

*東京工業大学 Tokyo Institute of Technology

Key Words：1）宸地保全，2）宸業労㑬力，3）中山間農菜集落，4）地縁集団（伝統的地域集団），5）農業継承性 
て，農家を構成する個人の持つ農業観を捉え，同 居家族の中で各世代相互の相違・一致構造をみる ことにより，意識の側面から農業と労働力の継承 性とを関連づけて分析する。

以上のように，(1)集落全体の土地所有・利用構 造, (2)農家家族単位でみた農業労偟力, (3)農家構 成貝個人の農業観の分析により, 農地の保全主体 としての農家と客体である農地の関係を把握し， 農業労働力の継承性との対応から中山間集落の農 地保全に関する課題を明らかにしていく（図 1)。

農業労働力を捉える方法としては，農家ごとの 労働人数, 各人の労働の程度や年龄等の属性との 関係でみる。農業の継承性に係わる意識の把握は, 既往研究注3) と同様に, 農家構成貝個々の農業観 や土地に対する意向を捉之，さらに同一家族内で の世代間の相違, 及び地域内での同世代間の比較 分析を行う。

研究対象地域は, 岡山県久米郡楖原町M集落で ある。この集落は中山間地域に位置づけられ，東 西 2 地区からなるが，それぞれの地区が社会組䅧 単位，すなわち日常生活圈域として一般の「集落」 という形態に極めて近い機能を有している。そこ で，対象地域全域の土地所有・利用状況を客観的 に捉える際には，M集落全域を对象として全体の 傾向を把握し,さらに現状の農家の労働力ゃ個人 の農業観等との対応分析では, 日常の地域社会と の関連が非常に強いと考えられるため，M集落西 地区を対象とし詳細な分析を行う。分析データは， 土地に関してはM集落全域的3,000筆の位置・地 目・面積・所有者・所有者の居住位置, 及び，農

\begin{tabular}{|c|}
\hline 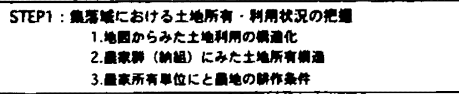 \\
\hline 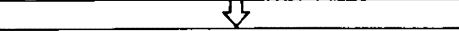 \\
\hline 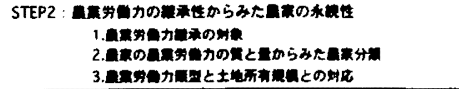 \\
\hline 5 \\
\hline 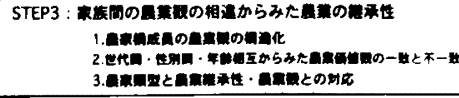 \\
\hline 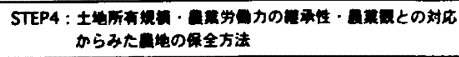 \\
\hline
\end{tabular}

業労働力・農業観等に関しては，西地区農家への アンケート・ヒアリンク調査によるデータ注4)を 用いた（表1，図2）。

\section{III 調査対象地の概況}

研究対象地域の農家構成は, 第 2 種兼業農家が ほとんどであり，ここ10年では離農・蜼村はわず かである。農業は主として自給・自家販売の稲作 が中心であり，烟作も宅地周辺の自給程度である。 かつては農業が主な収入源であり，農作業等を地 縁集団や集落内の親戚内で共同作業で行っていた が, 現在では個々の農家が個別に行う。しかし, 現在でも集落内の本家・分家，株内等のイエとし てのつきあいは密接である。また，近接する 7 . 8 戸の農家群で構成される地域社会単位は，この

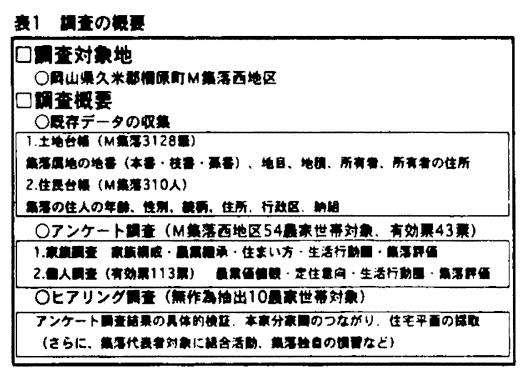
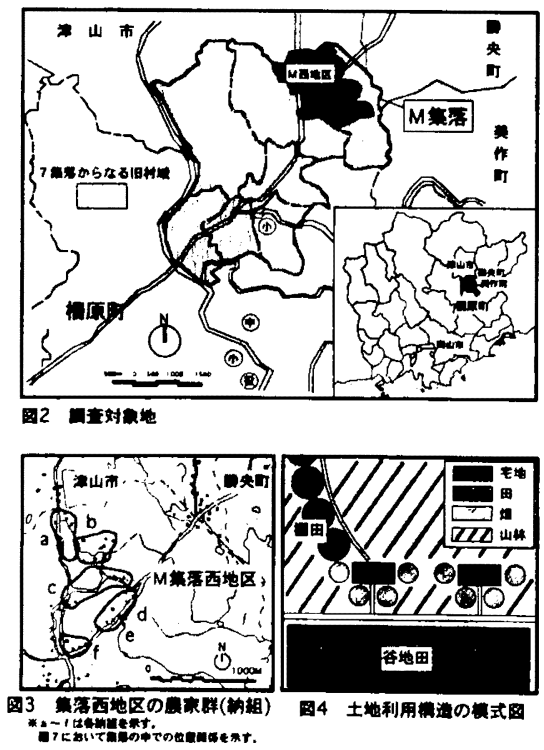
地域では「納組」注5)と称されている。図 3 に西地 区における納組の位置関係を示す。

土地利用の特徴は, 一般の山間集落同様に, 宅 地の周りに畑，さらに田，山林，及び山林に囲ま れた棚田というように，宅地を中心として生産空 間が面的に広がる層状構造である（図 4，図 5)。

土地所有の状況は，農地筆に関しては，集落外 居住者による所有ははとんどみられず，集落内農 家の個人所有がほとんどである。一方，策落の大 部分を占める山林筆は, 集落外居住者及び法人 . 行政等の個人以外の所有者も多く，特に宅地群か ら離れた集落の境界域で虫食い的に所有され，境 界付近の所有形癿の混在状況を示す证6) (図 6)。

\section{IV 中山間集落の土地利用構造 · 土地所有構造}

1 宅地群（納組）による土地所有域の形成

7 ・8 戸の宅地の集まりを一つの単位として, その所有農地の形成状況をみると，納組を構成す る農家群の土地所有領域は集団を構成する傾向が ある(図 7 )。この納組という集団は，現在でも 回覧板を回すといった行政末端連絡単位であると ともに，組織活動や祭事・清掃等をこの集団の単 位で行う。かつては農作業を共同で行った集団で

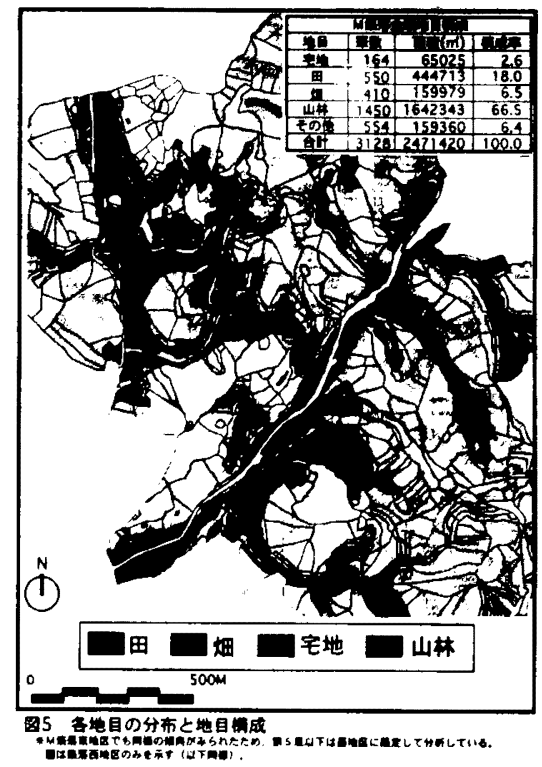

あり，居住生活単位と生産単位が一致していたこ とが伺える。農地以外の地目に関しては，納組に よる所有形態に規則性はみられず混在化を示すが, 農地筆に限ると，それぞれまとまった農地域を所 有しており，居住域（磭家群）と農地群（隣接す る農地䈇の集合体）との一体化した空間樓造が形
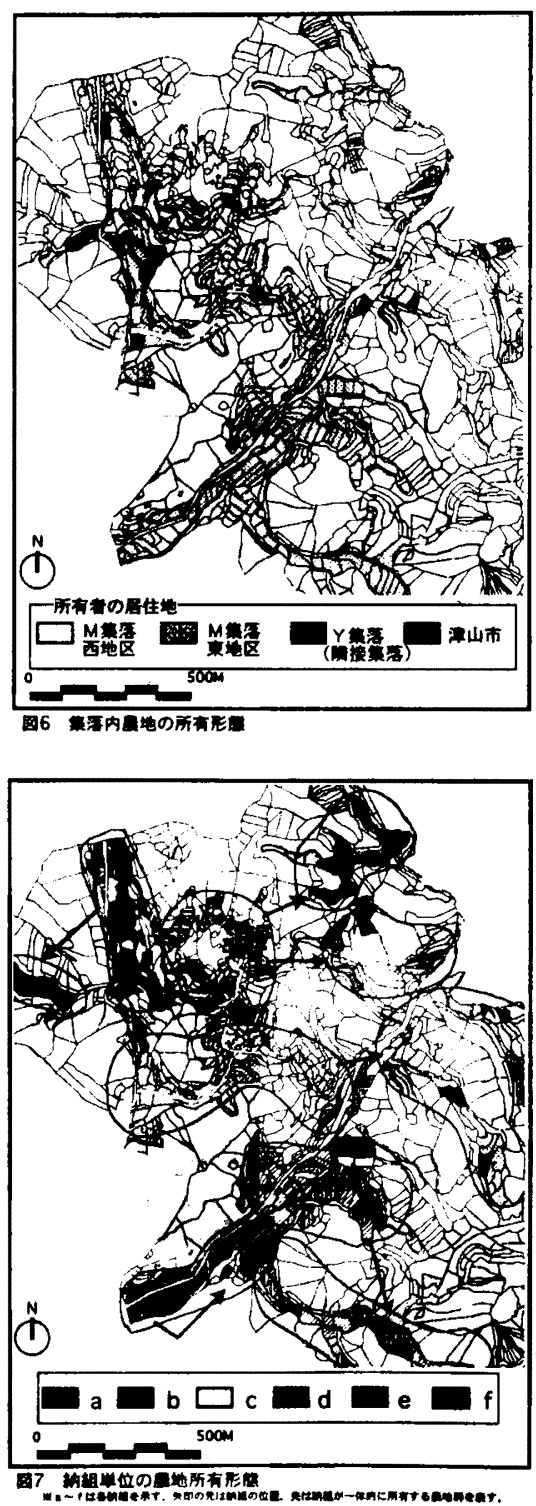
成されている。現在でも特殊な所有形態を維持す るこの地縁集団は，周辺農家どうしの土地利用上 の農地筆集積化や，地域としての展地管理運用 · 経営協力等の単位となり得, 農地保全を行う上で 重要な役割を担う主体として，現在でも充分機能 する可能性が大きいと考えられる注7)。

\section{2 土地所有規模階局別にみた土地所有形態}

まず，農地筆を中心とした土地所有内容を示す 指標で，農家の類型化を行なった。分析の対象は M集落に宅地筆を所有する122の者注8)とした。各 指標の固有値・固有べクトルを表 2 に示す。固有 ベクトルの絶対値の大小により嗉家を分類する軸 は, 1 軸「(+) 土地所有規模大 ( - ) 土地所有 規模小」， 2 朝「(-) 農地一 (+) 宅地の相対規

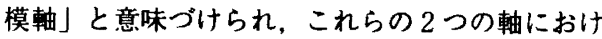
る粫家の主成分得点值の相互間距離からクラスター 分析 (ウォード法注9) によりT1からT 6 の 6 つに分類した（表 3 ，図 8 ）。分類された所有規 模階層別にみた, 所有平均筆数と平均面積, 納組,
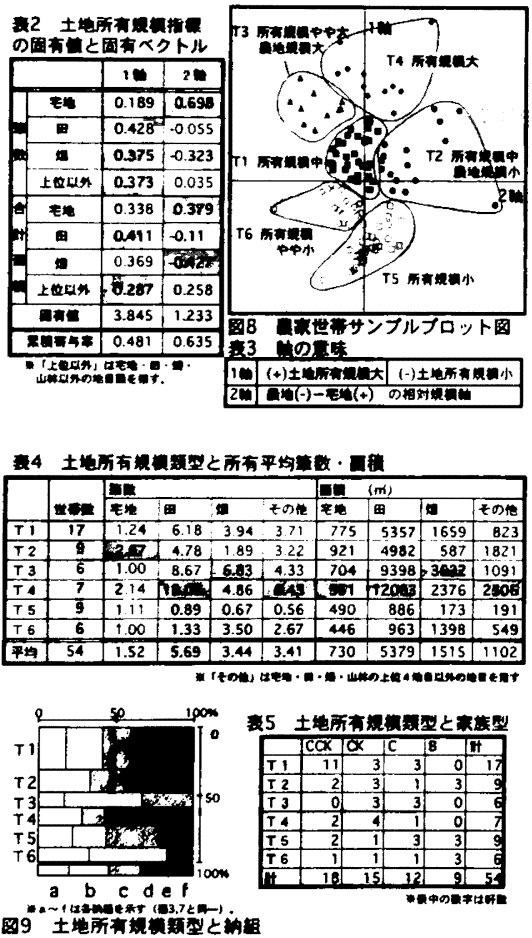

家族型脑10) との対応を表 4 ，図 9 ，表 5 に示す。 それぞれの特徴は以下の通り。

（T 1) サンプル数が最も多く, 宅地規模, 農地 規模とも平均的な類型。C C K型が多い。

（T 2）宅地規模が大きいが農地規模は小さい。

（T 3）宅地規模が小さいが農地規模は大きく， 特に他類型と比べて畑筆が多い。耕作条件の劣る 農地を所有する納組に属する。

（T 4）水田規模が相対的に大きく，耕作条件の 良い地を所有する納組に属する。

（T 5 ）耕作条件の悪い蔍地を所有する秋組に属 し，離農した農家が多い。農地規模は最も小さい。

（T 6 ）耕作条件の悪い農地を所有する納組に属 し，宅地規模，農地規模とも比較的小さい。

次に，分類された所有規模階層別に所有する農 地の位置を図10にみる。集落南部の耕作条件の良 い農地筆はT 4 とT 1 に多くの筆が所有されてい る。一方，耕作条件の悪い農地筆は様々な階層が 混在所有を示す。つまり，上位の土地所有規模階 層と農地の耕作条件とは相関を持つ傾向がある。 耕作条件の良い農地群においては大規模所有農家 による団地化所有形態注11)がみられ，一方で耕作 条件の悪い農地群では様々な農家階層の混在所有

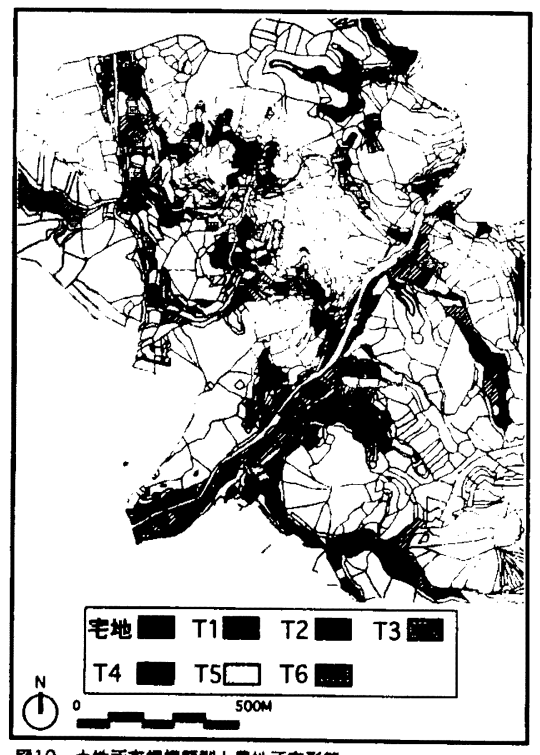

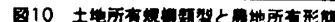


がみられる。後者の農地群では小規模所有農家に よる耕作放棄地の存在があり，隣接する大規模及 び中規模農家の所有する農地にまで影響を与え耕 作放棄化せざるを得なくなる等, 各階層の農家ま で巻き込んで集団的に耕作放菓化され，さらに拡 大していく可能性がある。

一般に経営が安定していると考えられている大 規模所有農家は，集落内に分散して農地を所有し ているものの, 耕作条件の比較的良い農地群にお いてはまとまった団地化所有形態がみられた。し かしながら, 特に条件の悪い農地群では点在所有 しており，耕作放菓地の搪大を防ぐような農地保 全策を検討していく必要がある。

V 農業労働力からみた農地保全と農業の 継承性

\section{1 農業労働力の捉え方}

より継続的かつ安定的な農業継承の可能性を探 り，個々の農家の農業労働力の継承を幅広く捉え るため, 親世代から子世代への農業の世代継承に ついて，農業後継者の存在のみではなく，傍系家 族まで含む親戚・姻戚を，さらには地域的な援農 として, 同じ地域社会の中の近隣農家, 地域組織 等までを農業労㗢力の担い手の対象とした。具体 的には，個々の農家の農業を継承していく可能性 のある対象者として，(1)同居家族：現在農業に従 事している者, 現在従事していない者, (2)現在同 居はしていないが将来戻ってくる可能性のある者 : 独身者, 既婚者，世帯主の兄弟・姉妹，と区分 しそれぞれについて，農業労㗢力の「量」を表す ものとして，人数，「質」を表すものとして，年 齢, 性別, 農業従事度, 農業経験の有無とし, さ らに近嚾農家や地域組織等の第三者への継承につ いての意向を捉え，農業労働力確保の内容を明ら かにしていく(図11)。

\section{2 労㗢力構成指標による農家類型}

各農家の農業労㗢力と所有する農地規模との関 連を見るため, 個々の農家の労㗢力構成から農家 の類型化を行った。対象は集落西地区の全農家で ある。分析手法は農業労働力の「量」「質」に関 する指標をもとにした主成分分析である。個々の 農家の現在の労働力（同居家族）状況を表すもの
としては，家族全体・主な労働力（主労働力者）

·手伝い程度の労働力注12）(従労働力者）・非農 業従事者，の 4 区分それぞれの人数と年齢活力 度注13)の 8 指標, 及び農業従事者男子率 1 指標の 計 9 指標。そして，現時点で考えられる将来の労 働力を表すものとして, 農業後継者の有無とその 年齢活力度の 2 指標。さらに, 別居家族への可能 性を表すものとして，独身者・既婚者・世带主 （またはその妻）の兄弟姉妹，3区分それぞれの 人数と年齢活力度の 6 指標, 及び別居家族の中の 農業経験者人数 1 指標を加えた 7 指標。合計 18 指 標を設定した（表 6$)$ 。

指標の固有ベクトルの絶対值の大小により農家 を分類する軸の意味づけを行うと，1軸は労働力 の安定度を表す軸と解釈でき，各農家の 1 軸の主 成分得点値がブラスに偏るほど，現時点の労働力 の量と質が充足している農家である。同様に，2 軸 $\Gamma(+)$ 同居労働力小 $(-)$ 別居既婚者依存度 大」, 3 軸「 $(+)$ 別居独身者依存度大 $(-)$ 同居 労働力大」と解釈できる。これらの 3 つの軸にお ける農家の主成分得点値の相互間距離からクラス 夕ー分析により，農業労働力から見たR 1 から R 7 の 7 つに分類した（図12，13）。各類型ごと の労働力構成指標の平均値, 所有平均筆数と平均 面積，世帯主の年龄，家族構成を表 7 ～10に示す。 各類型の特徵は以下の通りである。労働力類型と

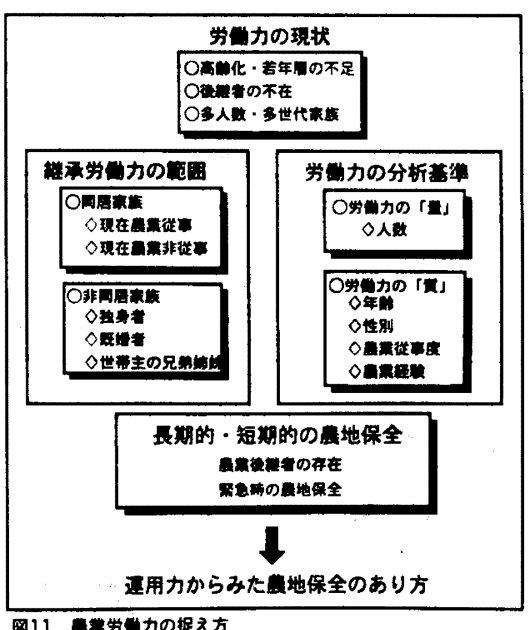

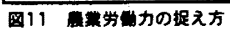


所属納組との関係はみられない（表11）。

（Ｒ１）「将来安定型」：同居家族の人材が豊富 で農業後継者も決まっており，所有する土地の規 模も大きく労働力とのバランスがとれ，世带主の 年龄も若く長期にわたって安定している。

（Ｒ２）「別居労倬力依存型」：別居している独 身者が多く、農業労倒力として可能性がある。所 有農地規模は平均以下。

（Ｒ３）「同居家族農外就労型」：同居家族の人 材は豊富であるが農外就労者が多く，別居家族内 でも農業労㗢力の人材がそしい。所有旅地規模は 平均以下。集落の約 $1 / 4$ を占め世带主は若く, こ の中間層が集落の将来を左右していくと考えられ る。

（R 4）「同居家族主労倬力（集落平均）型」： 所有宸地規模は大きいが労㰾力の条件はほほ平均 型。少ない同居労徽力範囲内で営農している。農 業後継者が確保できる可能性は半々であり，確保 している後継者は若手が多い。

（R 5 ）「主労㑬力豊富・別居労動力依存型」： 同居の人材が若く主労働力が豊富で農業後継者も 全ての家で決まっており，さらに別居家族の人材 が豊富で将来にわたって安定しているが, 所有す る土地の規模は集落平均並。

（R 6）「現況不安定・別居家族依存型」：老夫 婦のみの家族がほとんどであるが，世带主の別居 している兄弟の人材が豊富で，短期的な農業継続 は可能である。しかし，ほとんどの農家で農業後 継者が決まっておらず，長期的な展望が開けない。 所有農地の規模し大規模震家が存在し, 土地と労 働力のアンバランスが存在する。

（R 7 ）「将来不安定型」：現況労働力・別居家 族共に農業労動力人材がはとんどなく，離農傾向 にある。世帯主の年龄が若い農家とそうでない農 家の $2 つ に$ 分かれ，所有する農地も規模が多様で， 耕作放棄地の存在がある。

次に, 労働力階層と第三者への㖘地維持の可能 性，及び農業継承意識との相関を見るため，現在 の同居家族が急に㑬けなくなった場合等，緊急時 の農業労働力対策のための人材の有無（親戚・知 人・組織等の人材，及びその居所）と，農業後継 者に対して準備（その意向がある・実際にすでに
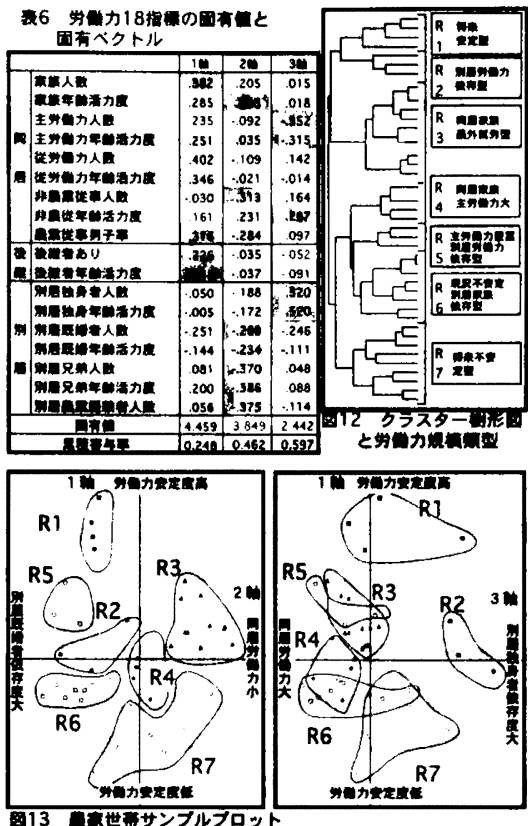

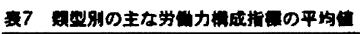
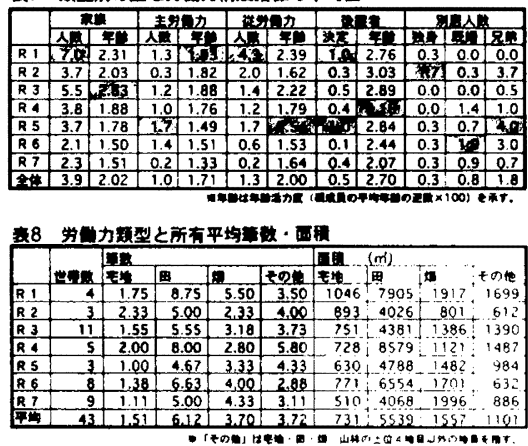

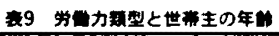

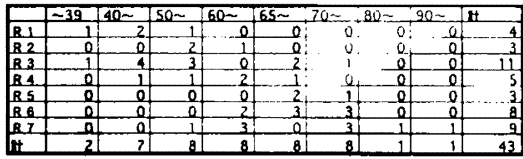

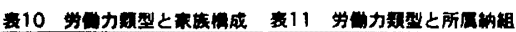

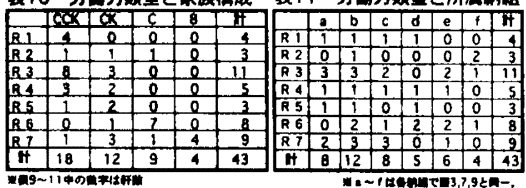


準備している) している内容を，類型ごとにみた ものが表12・13である。労働力階層に関わらず, 緊急時の農地維持は親威や知人，あるいは集落圏 域内の組織よりも，旧村・町レベルの組織への委 任がほとんどである注14)。後継者への準備は, 後 継者不在の多いR 6 や R 7 で意向がみられるもの の，実際の準備は集落全体においてはとんどみら れない。類型ごとに晨業とイエの後継者の存在を みると，R 6 とR 7 の労仿力の不安定な類型にお いて，イエの後継者は存在するが農業後継者が決 まっていない展家がみられる(表14)。これらが 所有する農地はほとんどが耕作条件が比較的悪い 立地であり，このように土地の素地条件が整って いない農家にとっては農業の継承はイエの継承よ りも困難な状況である。

\section{3 労倒力類型別にみた土地利用構造}

労俱力類型と土地所有規模類型との対応関係を みると, 各農家の労倒力と土地所有規模との明確 な関係はみられない(図14)。特に，労働力の不 安定な R 6 とR 7 の 2 類型に属する大規模所有農 家は, 農地保全のために将来的な農業労働力の維 持が必要とされる一方で, 将来の労働力が比較的
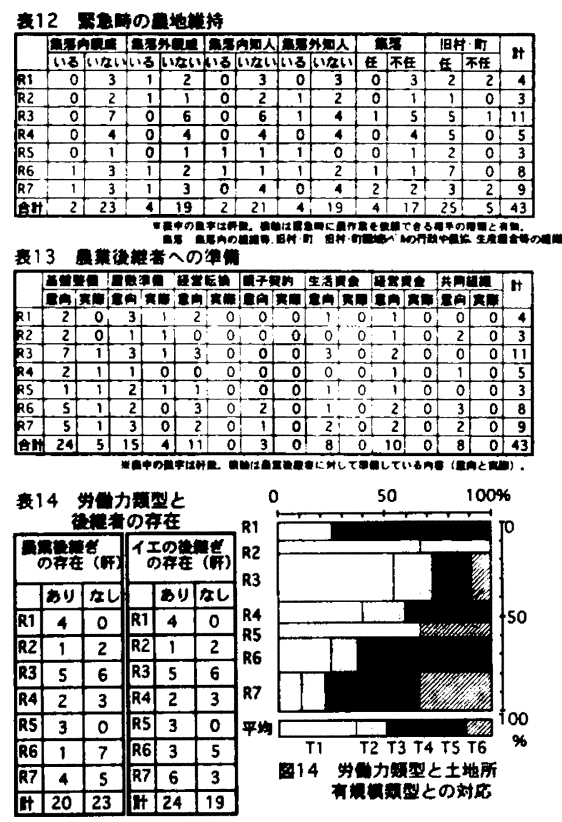

安定しているR 1 R 5 の類型には小規模所有農 家が存在し，農地所有規模と農業労働力のアンバ ランスな状況があり，而階層間での程営耕地貸借 等の㫳地保全策を考虑することが必要となる。

次に，労暻力類型ごとに所有する農地筆を図 15 に示す。土地所有規模類型ごとにみた展地所有形 態を表した図10と比較すると，耕作条件の比較的 悪い農地群は所有規模の大小の農家が混在して所 有しているが，労倠力類型からみても同様な状況 であり，所有規模・労倠力等，様々な階層による 所有農地の混在化を表している。

一方，耕作条件の良い展地群においては，大規 模所有農家の団地化所有形恁がみられたが, 学倠 力類型ごとにみると多くの蕽地が R 4 と R 6 の将 来の労倠力が安定していない類型に所有されてい る。 R 1による所有農地もみられるが, それらは R 4 や R 6 の所有農地に囲まれて存在する等, 集 落のいたるところに不安定農地が存在する。

以上のように，所有する農地規模と農業労働力 とは不均衡である場合も多く, 大規模所有農家が 地域の中核的農家とは必ずしもなり得ず，集落全 域にわたり将来不安定な農地が存在し, 耕作放棄 化が予想される。しかしながら, 様々な状態の農

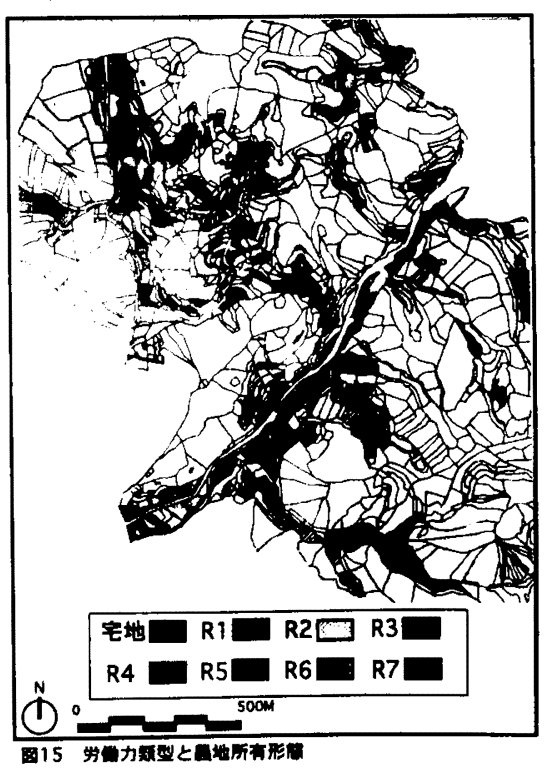


地の混在状況において, 各農家のみでの農地保全 は困難であるが，旧村・町圈域レベルの行政機関 や地縁組䅧等による地区全体への支援も考えられ る。

VI 農家家族世代間における農業観の継承性

\section{1 串家棈成員個人の業観による類型化}

農業を担う農家構成員個人の農地観・農業に関 する価値観の構造を把握するため，個人をサンプ ルとして主成分分析を行った。用いた指標は，客 観的な農業意識・農地の意味・農地及び農業の継 承・近所等との対人関係に関するものである。こ れら15指標の内容注15) と, 固有ベクトル, 固有値 及び累積寄与事を表15に示す。指標の固有べクト ルの絶対值の大小により個人を分類する軸の意味 づけを行うと，1軸は農業に対する票着度を表す 軸と解釈できる。同様に， 2 軸「(+) 継承意識 小 $(-)$ 楼承意識大」, 3 軸 $\Gamma(+)$ 客観的農業意
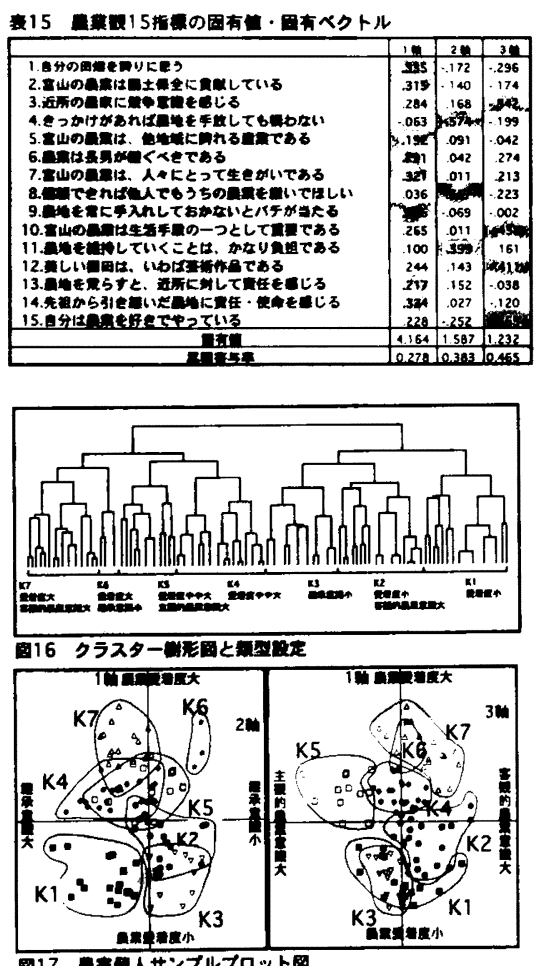

識大 (一) 主観的農業意識大」と解釈できる。こ れらの3つの軸における農家構成貝個人の主成分 得点値の相互間距離からクラスター分析により, K 1 からK 7 のつに分類した（図16）。個人サ ンプルの 1 軸から 3 軸までの得点值プロットを図 17に示す。また，各類型と個人属性との対応を表 16 20に示す。性別や農業従事度との明確な相関 はみられないものの, 各類型に属する個人の平均 年齢は，1軸に上る得点値の大小と一致すること から，年踰と展業愛着度の相関は高い。

さらに，丧家の所有規模類型, 労㗢力類型と, それぞれに属する個人の農業価値観類型との対応 をみる（表 $21 \cdot 22 ）$ 。大規模所有農家 T 4 の半数 がK 1 に属し，小規模所有宸家である T 5・T 6 は逆に，農業愛着度の高い類型に属する場合も多 く，家族の土地所有規模が大きくても，構成員個 人の農業愛着度が高いとは限らない。また，現段 階での労働力が極めて小さいR $6 \cdot R 7$ に属する 個人は, $\mathrm{K} 3$ p 6 等の離農意向の高い類型には 属さず，誇り高いK 5 類型や爱着度の高いK 7 類 型に属し, 労働力が小さくても意地を張って農業 を営もうとする農家の存在がみられる。

2 農家家族内の世代間における農業観の継承性

農家家族の中で，また地区全域の中で個人の農 業観の相違・一致楎造を捉えることにより，親世 代と子世代等, 家族内での各世代間にわたる農業 観の継承性をみる。図17の個人得点值プロット図

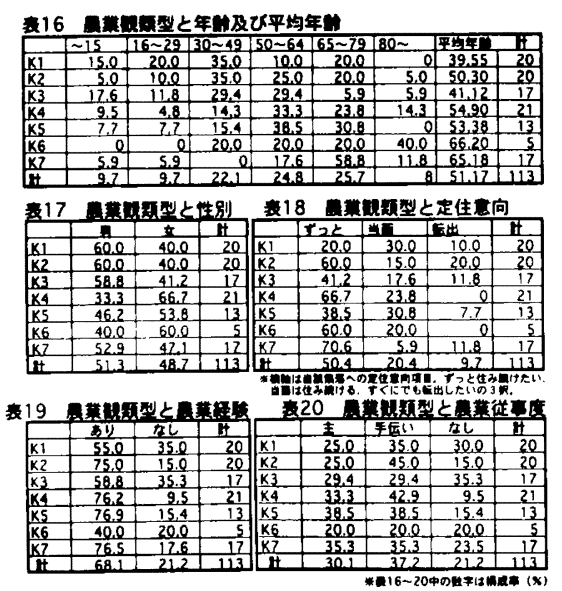




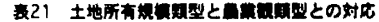

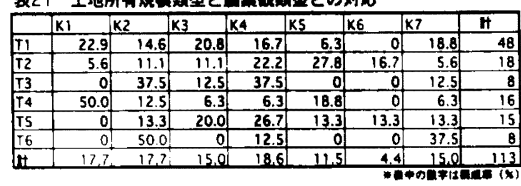

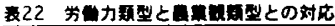

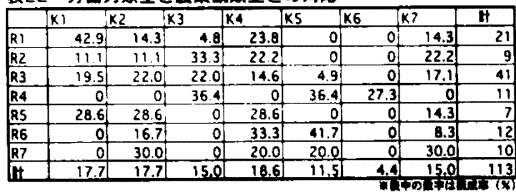

での同家族を相互に線で結び，各家族ごとの世代 間の農業観の相違を捉える（図18）。

どの労働力階層においても，同世代どうしの農 業観は 1 軸の得点値の差が小さいことから，その 相違は小さいと判断できる。 R 1・R 3にみられ るように，多世代家族では農業愛着度の高い上の 世代どうしが近い農業観を持ち，農業爱着度の低 い下の世代とは差がみられる。

世代間における意識の相違が小さく，積極的農 業意識を持つ類型に該当する家族の存在は, 多世 代にわたる農業経営の安定した方向性を意味する。 そこで，労動力規模が地区内の階層分布において 中間層である R 2 R R についての農業観を分析 し, 大規模労鱽力農家に次ぐ集落の農地保全の担 い手としての可能性を検討する。 R 2 農家は, 1 家族のみが積極的な農業観を持つ。中でも地区内 の階層分布の中で最頻値をとる R 3 は，世代間の 農業観が一致しない農家が多く，一致・類似構造 を示す農家はわずかである。さらにR 4 には農業 愛着度の高い家族がみられるものの，同時に離農 意向も大きい。このように，笨落の中間層におい て，世代間で農業観が積極的な内容で一致した農 家はごくわずかである。

一方, 労働力の安定したR 1・R 5 に属する農 家は，全体として意識が消極的な傾向を持ち，労 働力の不安定な R 6 P R 7 に属する農家は，高龄 者夫婦のみの家族が多いが，お互いに積極的な農 業意識を持つ農家が多い。すなわち，農家世帯の 労㗢力の安定性と農業意識・農業価値観の積極性 及び継承性との対応はみられない。

以上のことから，世代間の農業観の一致・不一

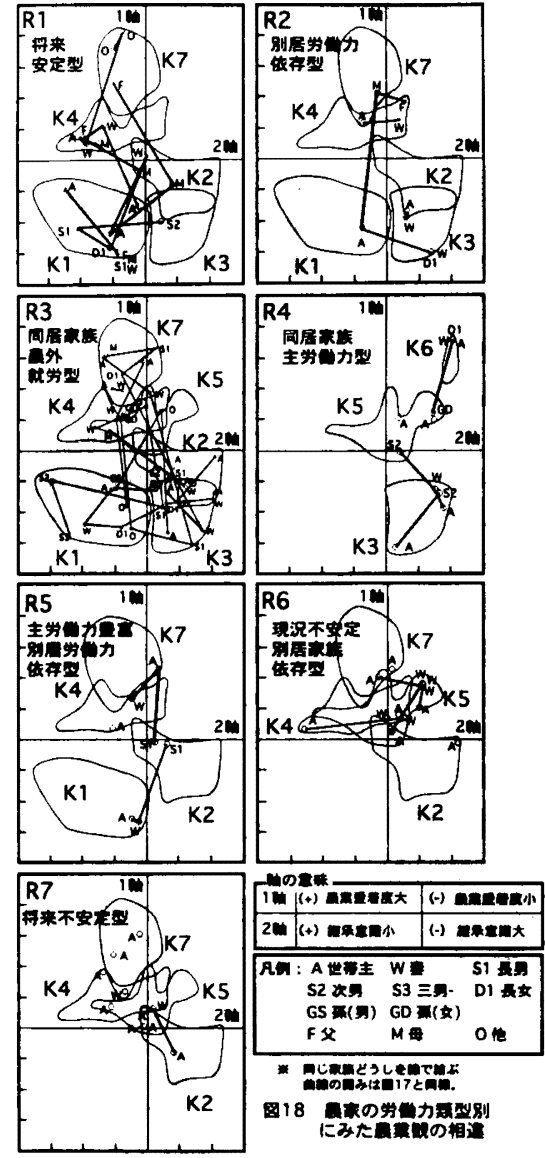

致については，概して，親世代が積極的意識を持っ ていても子世代の継承意向は少なく，意識が一致 する場合は消極的価値観で一致する。また，農家 の労働力の安定性と農業観の世代間での継承性は 比例せず，土地の素地条件とその運用力，及び農 業観の側面の全てにおいて安定した方向性を持つ 農家は現状では非常に少ない。

VII まとめ

中山間地域の集落における農業労働力の継承の 特徵と今後の農地保全のための計画課題について, 結論を以下に述べる（図19）。

（1）一般に農村地域では，組織活動や祭事，環境 


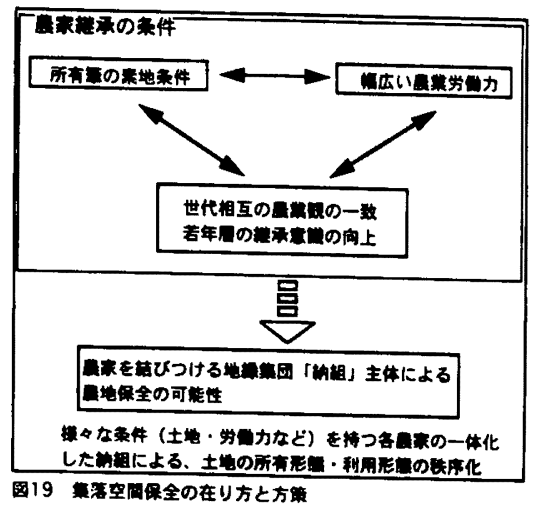

整備・清掃等を，旧来からの地緑集団により，慣 習的な方法で行っているが，これらはかって共同 で晨作業を行った宅地の集団であり，農地の管理 運用を基盤に成立している。本研究の対象地域に おいても,これらの宅地の集団による明確な農地 所有の形態が認められ，それぞれが宅地群から離 れた地域においてもまとまった宸地群を所有して おり, 現状でも農地の運用・管理の側面では機能 を果たし得ることが求められた。従って，これら の地縁集団を再度見直し, 重要な計画単位として 用いることにより面的な農地の保全が可能となる。 （2）土地所有規模と集落内農地の耕作条件とは一 定の関連性を持つ。耕作条件の比較的優れた農地 群においては大規模所有宸家による団地化所有の 形態がみられ, 耕作条件の比較的悪い農地群では 様々な所有規模農家が混在する。農業労㗢力の面 では, 現況の同居家族による労㰾力が不足し, 労 働力を傍系家族に依存せさるを得ない層が多く存 在する。また，農家の土地所有規模と労働力とは 明確な相関がみられず，大規模所有でありながら， 労㗢力が小規模不安定といった不均衡が生じ，耕 作放呆化も予想される。耕作条件の比較的良い農 地群においても, 様々な労僖力の農家が混在的に 所有しており，農業継続の不安定な農地が集落の 至る所に存在する。その不安定農地を中心に地域 全体に耕作放菓化が進行する可能性が高く，大規 模所有農家が地域の農業の担い手になり得ること は必ずしも無い。一方, 所有農地の労㗢依頼先, すなわち将来にわたる農地保全をみすえた農地の 預け先としては, 特定の農家ではなく旧村や町と
いった圈域レベルの行政機関や組織等への信頼性 が高く，先に挙げた納組という地縁集団に対して, 行政による支援や制度としての保障を与える等の 施策と並行して、この単位の中でどのように労働 力を確保するかが今後の課題である。

（3）宸家の中での個人の宸業観の相違をみると， 世代間の農業観の不一致傾向が強く, 多世代にわ たって農業観が積極的意向で一致する家族は非常 に少ない。一致する場合でも，その内容は消極的 ・雜農意識であることが多い。農家の労㗢力の安 定性と農業観の積極性とに相関が存在しないのが 現状であり, 労働力の「贯」の継承と農業観とい う「質」の継承が一致している農家は少く, 個々 の農家のみによる農地保全の継続は非常に困難で あるといえる。

以上, 本研究では農家の農業労働力及び農業観 の継承性から中山間集落の蕽地保全の方向性を求 めた。農地の所有主体である農家家族では, 労㗢 力の継承がスムースに行われることは少なく，条 件不利といわれる中山間集落においても，その中 で様々な条件の農地・家族・個人か存在しており， 個人の農業に関する価値観は，おかれている立場 ·条件とは必ずしも一致しない。各農家の農業継 承の条件は，所有する農地の素地条件だけでなく， 運用力（農業労働力）の幅広い確保，家族内にお ける世代間の農業観の一致, 若い世代の農業観 · 集落保全意識の向上にある。条件不利な中山間集 落においては特に, 個々の農家による各所有農地 に対する対応のみでの農地保全は難しく, 地域全 体としての農業経営を実現することが有効である。

注视

注 1) 継承とは「先代・先任者などのあとをうけつぐ こと」(広辞苑)。本研究における継承とは, 農家 家族における上の世代から下の世代への農業に関 することがらの引継きをさす。本稿で，農村地域 における「継承」とは，まず，農業の継承（家業 としての農業の存続)，イエの継承（イエの血族 的な存繶，及ひ不動産としての住宅や農地の相続)， そして，宸村としての地域の継承（農業を行うイ 工の存続, 及び農村風景や農地の保全) 等が挙げ られるか，本研究では主に，農家が所有する農地 における晨業労鲃力の継承性を取り扱い，それに 
係わる個人の晨業観，及び同居家族の中の意向の 相違を併せて分析することで，将来にわたる農地 保全と丧業継続の可能性を捉えている。

注 2) 参考・引用文献 1)，2）参照。

注 3）参考·引用文献 3），4）参照。

注 4 ) 本研究では，土地台帳データのほかに，宸業钼 後継者に阔するアンケート調査（配布展家数 54 ·有効票農家票43, 農家搆成員個人罧113）及び, 慰業観・後継者・生活・屋教空間に関するヒアリ ング調查（無作為抽出10鋠家）によるデー夕を取 ク扱った。なお，ヒアリンク調查等の結果より，

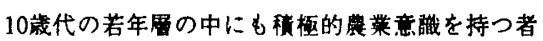
など，農地保全及び集落空間の維持保全に䦕して， 将来の担い手となるべき人材が存在することが明 らかになった。そのため個人対象のアンケートは 10歳代の若年者（小学生高学年以上）に対しても 調査を行っており，啠問をかかりやすい表現に直 し大人（高校生以上）と同様の回答を求めている。

注 5) 参考·引用文献 5)，6）で, 集落内の行政末 端連絡単位として「瑟」と呼ばれるものと同様な 性格を有する地域社会的な単位である。参考・引 用文献 7 )によれは，「納組」以外には，「坪」 「谷戸」等と呼ばれる同種の単位が全国に存在す る。

注6）箻者らの既往研究（参考・引用文献 8），9）） でもほほ同様な結果が得られた。

注 7 ) 管者らの既往研究（参考·引用文献10，，11)） では，曟地保全と耕作・展業释営の効率化を目的 とした宸地筆の集程化や，共同経営の際の農地利 用におけるソーニングを検討する際には，農家の 階層にかかわらず簕の条件に着目すれば，農家の 自宅との相対的な位量関係から，条件の悪い鹿地 を集落全域で入れ替え，再編成することにより， 通作条件の向上や自宅周辺での団地域の形成など, より奻率的な地域の宸業の释営体制を整備するこ とが可能となること等を求めている。従って，本 稿における「納組」が現状においてすでに，日常 生活及び土地所有形態，西面においてある程度ま とまりのある単位であることは，将来に向けた共 同経営等に非常に有利に㑬く可能性が大きいと考 察される。

注 8）122の者の居住地の内訳は，西地区54 - 東地区41 ・その他27。宅地筆を所有する者は，実際に住ん でいる者または住む意図がある者のいずれかと考 えられ，将来にわたる集落全体の屡地保全を扱う
ためにこのように設定した。

注 9).クラスター間の距離阜算方法は，クラスターの

重心まわりの偏差平方和を最小にするように他の クラスターと融合させ，対象の分布密度の高いと ころからグルーブを形成させるためウォード法を 用いる。得点値間の距離計算方法にはユークリッ ドの平方距離を用いる。

注10）家族型は，家族社会学等で一般に使われている， 多世代家族 $\mathrm{C} \mathrm{CK}$, 核家族·子供あり $\mathrm{CK}$ ，核家 族・子供な LC，単身家族 B，の表記方法を用い た。

注11）㮴数の绦接した震地をまとめて集合的に所有す ろ形憼を指す。

注12）アンケート拥査では，農莱従事度として，各家 族輌成貝個人に対し，「主な労倠力」「手伝い程度 の労佰力」「なし」の 3 つの選択肢を問い，農業 従事への参加形態を把握した。

注13）平均年袷の逆数に100を稳した数で、この值が 大きいほどその集団の年龄的活気があるとした。 なお，ある集団の樓成員が0人の場合，暫定的に その年龄活力度の值は 0 として取り扱った。

注14）地域営晨に関して「集落内の近隣または中核的 農家といった個人ょりも，旧村や町图域レベルの 行政機夙や組織等に依頼したい」という意識の衰 付けとしては，農家10件のヒアリンク調査により， 「収入の大半が農莱でまかなっており，納組単位 の表家が協力せさるを得ない状況であった従来の スタイルと異なり，現在では慰業（イエの一職業） に䦎して，近隣の農家とあまり頼り合わないよう にしている」，といったような傾向を菜いた。す なわち，地域組繶は時代と共に生産活助から乘離 し、共有道路や神社等の空閜維持, 地域の楽しみ 活助のみにシフトしていることが伺える。

注15）展業経営意向，展地の保全意識，及び展業自体 への価値钼等，展業钼を表す15指標については， 「はい」または「いいえ」の回答形式を探った。

$$
\text { 参考・引用文献 }
$$

1）森川稳ほか「農山村転出後継者の掃逼意向に関す る分析 滋賀県高島郡朽木村における転出・㷌遇 移動に閔する研究その1」日本建築学会論文報告 集第339号 昭和59年 5 月 pp. 112-121

2）森川琴ほか「慰山村における㷌還者及び新来者に 関する研究 滋贺県高島郡朽木村における転出・ 㛿這移動に関する研究その $2 」$ 日本建築学会計画 
系論文報告集 第353号 昭和60年 7 月 pp. 92-101

3）系長浩司，青木志郎，蓝澤宏ほか「地方都市近郊 村地域での宅地化特性と住民の宅地化評価に関 する研究」農村計画学会誌 1986.3 pp. 5-18

4 ）日下正基「都市内農地保全に関する基碇的研究 (その 3 )」日本建築学会論文集第 271 号 昭和 53 年 9 月 pp. 105-111

5）伊藤庯一「近郊晨村における地域的な活動単位に 関する考察」日本建築学会計画系論文報告集 第 392 号 1988.10 pp. 127-135

6) 同「農村集落における社会集团の重層的な粠成に 関す万研究」日本建等学会計面系論文報告集 第 403号 1989.9 pp. $105-113$

7 ）渡辺兵力編著「農業集落論」能溪㫪舎 1978

8）蓝瀑去ほか「晨村地域における土地所有圈域棈造 に関する研究」日本建築学会計画系論文集 第457
号 1994.3 pp. $133-142$

9 ）蓝澤宏ほか「土地所有規模階層の相違からみた宸

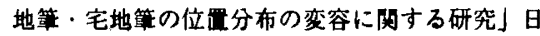
本建築学会計画系論文報告集 第426号 1991.8 pp. $111-119$

10）藍澤宏ほか「集落立地別による農家の農業観・脤 業経営意向・展地保全意向の粠造化に関する研究

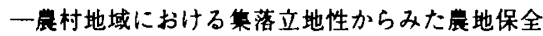
に関する研究その1一」日本建策学会計画系論文 報告集 第495号 1997.5 pp. 131-137

11）蓝潀宏ほか「集落立地別による晨地の所有・利用 圈域に関する研究一農村地城における集落立地性 からみた農地保全に閏する研究その 2 一」日本 建築学会計画系論文報告集 第506号 1998.4 pp. $81-88$

This study will investigate the direction of farmland conservation in a settlement of hilly and mountainous farming area, from the viewpoint of the continuity of farmer's agricultural view and agricultural labor force. The research field was $\mathrm{M}$-settlement, which is a typical settlement of hilly and mountainous farming area, in Yanahara-cho, Kume-gun, Okayama-ken.

The first part dealt with land use and possessing structure in the research field. The main results obtained are as follows;

1) The land possessing structure by traditional community unit which is called as "Nou-gumi", still remaines and it gives marked effects on the present land use.

2) Advantage for cultivation was highly related to the land possessing structure.

The second part studies on continuity of agricultural labor force in large-scale farms. The results obtained are as follows;

1) The correlation between land scale and agricultural labor force in each farm was not always clear and unbalanced conditions were sometimes found even in large-scale farms.

2) The abandoned cultivation often occurred due to shortage of labor force in the farmers which had the advantage of land.

The third part developed practical plans for land use and conservation through attitude survey for individuals in households, according to the results obtained in the first and the second parts;

1. In order to plan land use and conservation in the future, the traditional community unit which decides the habitants' attitude for agricultural production and living space in the settlement, had to be suggestively considered as the base unit of farmland management and use.

2. Not only land quality but also many conditions such as continuity of agricultural labor force, agreement of thinking way from youth to aged generation in a household, seemed to be necessary due to continue the cultivation.

Key Words : 1) farmland conservation, 2) agricultural labor force, 3) settlement of hilly and mountainous farming area, 4) traditional community unit, 5) continuity of cultivation 